\title{
Removal of high-strength of ammonium and phenol from coking wastewater by Alcaligenes faecalis No.4
}

\begin{abstract}
Alcaligenes faecalis No.4, which is capable of heterotrophic nitrification and aerobic denitrification was used to treat coking wastewater $(\mathrm{CW})$ to remove high-strength of ammonium and phenol. First, the phenol-degrading ability of No.4 was verified and a synthetic medium containing lactate and phenol as carbon sources was subsequently applied to the No.4 culture. Both carbon materials were entirely utilized for the complete consumption of ammonium. Next a coking wastewater containing $400 \mathrm{mg} / 1$ of phenol and $400 \mathrm{mg} / 1$ of ammonium-nitrogen was treated by the No.4 culture. Both compounds were completely removed through the addition of $4 \mathrm{~g} / 1$ of lactate. The removal rate of ammonium was $1.1 \mathrm{~kg}-\mathrm{N} / \mathrm{m}^{3} /$ day which is several hundred-fold higher than that in conventional treatment system.
\end{abstract}

Keywords: heterotrophic nitrification, aerobic denitrification, high-strength ammonium, alcaligenes faecalis, phenol-containing wastewater
Volume I Issue 3 - 2016

Makoto Shoda, Ishikawa Y
Able Corporation, Japan

Correspondence: Makoto Shoda, Able Corporation, 7-9 Nishigoken-cho, Shinjuku-ku, Tokyo, 2 |6-08| 2 Japan, Tel+8I-3260- 0485, Fax+8I-3-260-0485, Email mshoda@res.titech.ac.jp

Received: September 19, 2016 | Published: December 30, 2016
Abbreviations: DO, dissolved oxygen; $\mathrm{CW}$, coking wastewater; EDTA, (2,2',2",2"'-(Ethane-1,2-diyldinitrilo)tetra acetic acid

\section{Introduction}

Coking wastewater $(\mathrm{CW})$ originates from the process of destructive distillation of coal at high temperatures in the absence of air. Phenols are the major constituents of the coking wastewater and can seriously inhibit various biological reactions, especially the nitrification reaction. Conventional biological treatment is difficult mainly due to refractory substances. When high-strength ammonium is involved in $\mathrm{CW}, \mathrm{COD}$ in the wastewater is not sufficient to complete the removal of ammonium. ${ }^{1-5}$ Recently, many bacteria have been known to be capable of heterotrophic nitrification and aerobic denitrification. ${ }^{6-14}$ The use of these bacteria provides advantages over the conventional nitrogen removal process of aerobic nitrification and an anaerobic denitrification because ammonium removal is achieved in one reactor using one type of bacteria under aerobic conditions. These ammonium removal rates are higher than those in conventional ammonium removal process, primarily because of short hydraulic retention time. In a previous study, ${ }^{15}$ we demonstrated that $A$. faecalis No.4 (No.4) has the ability to carry out the following heterotrophic nitrification and aerobic denitrification

$$
\mathrm{NH}_{4}^{+} \rightarrow \mathrm{NH}_{2} \mathrm{OH} \rightarrow \mathrm{N}_{2} \mathrm{O} \rightarrow \mathrm{N}_{2}
$$

Approximately $40 \%$ and $60 \%$ of ammonium were converted to $\mathrm{N}_{2}$ gas and cell mass respectively and only a small amount of ammonium was converted to $\mathrm{NO}_{2}^{-}$and $\mathrm{NO}_{3}^{-}$. No.4 removed more than $90 \%$ of high-strength ammonium and COD from crude piggery wastewater without diluting it. ${ }^{16}$ No.4 also exhibited an ammonium removal rate of $3 \mathrm{~kg}-\mathrm{NH}_{4}-\mathrm{N} / \mathrm{m}^{3} /$ day in the treatment of anaerobically digested sludge from a municipal wastewater plant. ${ }^{17} \mathrm{~A}$ wastewater from a chemical company, which contained a high concentration of ammonium $\left(5,000 \mathrm{mg}-\mathrm{NH}_{4}-\mathrm{N} / \mathrm{L}\right)$ and a small amount of BOD was treated by No.4 and the average ammonium removal rate was $1.1 \mathrm{~kg}-\mathrm{NH}_{4}-\mathrm{N} / \mathrm{m}^{3} /$ day. ${ }^{18}$ These removal rates by No.4 were several hundred-fold higher than that in conventional treatment method. ${ }^{19,20}$ In this study, No.4 was applied to a coking wastewater supplied by a chemical company to assess the effects of biological treatment of high-strength ammonium and phenol using a 1-liter jar fermenter.

\section{Materials and methods}

\section{Strain used}

Characteristics of No.4 have been previously described in details. ${ }^{11}$ Cultured cells of No.4 were mixed with a $50 \%$ glycerol solution in vials and stored at $-84^{\circ} \mathrm{C}$. For each pre-culture one vial was used as the No.4 inoculum.

\section{Medium used}

A synthetic medium containing $14 \mathrm{~g} / 1$ of $\mathrm{K}_{2} \mathrm{HPO}_{4}, 6 \mathrm{~g} / 1$ of $\mathrm{KH}_{2} \mathrm{PO}_{4}$, $12.5 \mathrm{~g} / \mathrm{l}$ of sodium lactate, $2 \mathrm{~g} / \mathrm{l}$ of $\left(\mathrm{NH}_{4}\right)_{2} \mathrm{SO}_{4}$ and $0.2 \mathrm{~g} / 1$ of $\mathrm{MgSO}_{4} .7 \mathrm{H}_{2} \mathrm{O}$ and $2 \mathrm{ml}$ of trace mineral solution was used for the pre-culture of No.4. The trace mineral solution contained the following components ( $\mathrm{g}$ per liter): 57.1 EDTA (2, 2', 2", 2"'- (ethane-1,2-diyldinitrilo)tetra acetic acid) $2 \mathrm{Na}, 3.9 \mathrm{ZnSO}_{4} \bullet 7 \mathrm{H}_{2} \mathrm{O}, 7 \mathrm{CaCl}_{2} \bullet 2 \mathrm{H}_{2} \mathrm{O}, 5.1 \mathrm{MnCl}_{2} \bullet 4 \mathrm{H}_{2} \mathrm{O}$, $5.0 \mathrm{FeSO}_{4} \bullet 7 \mathrm{H}_{2} \mathrm{O}, 1.1\left(\mathrm{NH}_{4}\right)_{6} \mathrm{Mo}_{7} \mathrm{O}_{24} \bullet 4 \mathrm{H}_{2} \mathrm{O}, 1.6 \mathrm{CuSO}_{4} \bullet 5 \mathrm{H}_{2} \mathrm{O}$ and $1.6 \mathrm{CoCl}_{2} \bullet 6 \mathrm{H}_{2} \mathrm{O}$. No.4 utilizes fatty acids as a carbon source and in a previous study citrate was used. When lactate and citrate were compared as carbon source the ammonium utilization rate and the growth rate of No.4 were significantly higher than those when lactate was used. Therefore, lactate was used in the following experiments. The synthetic medium was sterilized for the use of pre-culture but in batch treatment culture, no sterilization was conducted. Phenol was added without sterilization.

\section{Wastewater used}

The coking wastewater (CW) was supplied by a Japanese chemical company. The primary characteristics of the $\mathrm{CW}$ are as follows: $\mathrm{pH}$ 8.5 , total COD concentration of $5,200 \mathrm{mg} / \mathrm{l}$, ammonium-nitrogen concentration of $800 \mathrm{mg} / \mathrm{l}$ and phenol concentration of $820 \mathrm{mg} / 1$. In each experiment the $\mathrm{pH}$ of the original $\mathrm{CW}$ was adjusted to approximately 7.5 by $5 \mathrm{NH}_{2} \mathrm{SO}_{4}$ and the $\mathrm{pH}$-adjusted $\mathrm{CW}$ was diluted arbitrarily. 


\section{Reactors used}

A small-scale jar fermenter (total volume of 1 liter, working volume of 300ml; BMJ-01PI, Able Corp., Tokyo, Japan) was used. The dissolved oxygen (DO) concentrations and $\mathrm{pH}$ values were monitored with a DO sensor (SDOC-12F, Able Corp., Tokyo, Japan) and a pH sensor (Easyferm plus 225, Hamilton Bonaduz AG, Bonaduz, Switzerland) inserted into the fermenter. The temperature was maintained at $30^{\circ} \mathrm{C}$. The agitation speed was controlled at $600 \mathrm{rpm}$ with a constant air supply rate of $30 \mathrm{ml} / \mathrm{min}$.

\section{Experimental procedure}

The synthetic media were prepared in the pre-culture of No.4 containing lactate $(10 \mathrm{~g} / \mathrm{l})$ and phenol $(0.2 \mathrm{~g} / \mathrm{l})$ or lactate only. No.4 was cultivated in the two media for 3 days, when lactate and phenol were consumed completely. Next, the pre-cultures were centrifuged at $10,000 \mathrm{rpm}$ for $10 \mathrm{~min}$ and the collected cells of No.4 were washed with $0.1 \mathrm{M}$ phosphate buffer two times. The cells were inoculated into the synthetic medium which was devoid of lactate and contained only phenol as a carbon source. In CW treatment, pre-cultured No.4 cells were introduced into different dilution $\mathrm{CW}$ and the growth of No.4 was confirmed at $50 \%$ dilution in shaking flasks. The diluted $\mathrm{CW}$ was added with lactate and No.4 culture in jar fermenter and ammonium removal test was conducted.

\section{Analytical method}

Ammonium concentration was determined using an ammonium sensor (SNH-10, Able Corp., Tokyo). For phenol concentration determination, the chemical analysis kit for phenol (LR-PNL, Kyoritsu Chemical-Check Lab., Corp., Tokyo, Japan) was used. The initial and final values of TOC in the prepared solution were determined at Kuritasu Analyzing CO., Ltd., (Tukuba, Japan). For determining the cell number of No.4, the sampled culture was diluted and plated on the synthetic agar plates which contained the synthetic medium and 1.5\% agar and then the plates were incubated at $30^{\circ} \mathrm{C}$ for 2 days. Since it was previously confirmed that No.4 grew on the plates significantly faster than other cells indigenous to the $\mathrm{CW}$ and exhibited their characteristic morphological features the colonies appeared on the plates after 2 days were counted as No.4. The cell concentration was expressed as cells/ $\mathrm{ml}$. The crude coking wastewater was streaked on the LB medium and the synthetic agar medium and no colonies appeared after 3 days of incubation. Therefore, indigenous microorganisms in the crude coke-production wastewater were negligible in number. The air was supplied to the $\mathrm{CW}$ sample containing lactate in the jar fermenter for 4 days and neither the removal of lactate nor ammonium was observed and thus the air-borne microorganisms from outside reactor were also negligible in the treatment.

\section{Results and discussion}

\section{Availability of phenol by No.4}

Figure 1 shows the change in concentrations of ammonium and phenol in the synthetic medium devoid of lactate when phenol was not added in the pre-culture. Figure 2 shows the change in concentrations of ammonium and phenol when phenol was added in the pre-culture. Comparison of the two figures, phenol degradation rate and ammonium removal rate were $38(\mathrm{mg} / \mathrm{l} / \mathrm{h})$ and $5.3(\mathrm{mg} / \mathrm{l} / \mathrm{h})$ for Figure 2 and 31 and 4.1 for Figure 1, respectively. As shown in Figure 2, $18 \mathrm{~h}$ were needed for the complete removal of phenol while $22 \mathrm{~h}$, as shown in Figure 1. This finding indicates that phenol was utilized by No.4 and the induction of phenol-degradation ability by phenol in the pre-culture was associated with the enhanced removal rates and shorter time to exhaust phenol. At the moment when phenol was exhausted, DO rapidly increased, indicating that the consumption of phenol and DO change were well-correlated. When the initial phenol concentration was $600-700 \mathrm{mg} / 1$, this includes $459-535 \mathrm{mg} / 1$ of carbon. If the $\mathrm{C} / \mathrm{N}$ ratio of cell synthesis was 10 , consumption of 600 to $700 \mathrm{mg} / 1$ of phenol corresponded with the consumption of only approximately 50 to $60 \mathrm{mg} / \mathrm{l}$ of ammonium-nitrogen. The consumption of ammoniumnitrogen in Figure $1 \& 2$ well reflected the ratio. The ammonium removal rates using phenol as a carbon source in the two experiments were $0.098-0.12 \mathrm{~kg}-\mathrm{N} / \mathrm{m}^{3} / \mathrm{day}$, which is approximately one-tenth of the rate when fatty acids were used as a carbon source. However, these data were approximately 10 -fold higher than the rate in conventional nitrification-denitrification method. This finding suggests that for complete removal of ammonium in $\mathrm{CW}$, addition of available carbon for No.4 is needed.

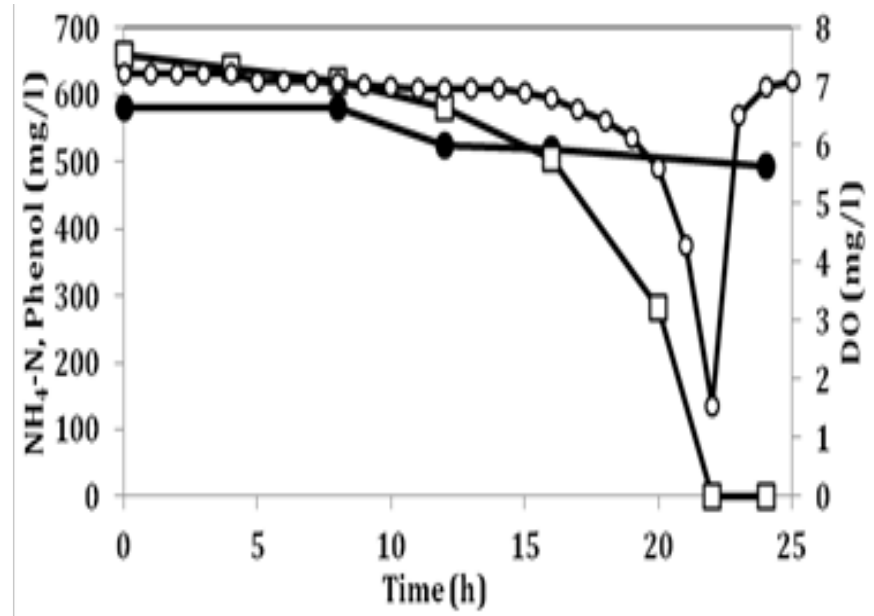

Figure I Removal of ammonium and phenol in synthetic medium, where phenol is a sole carbon source by No.4 when lactate was used as a carbon source in pre-culture.

Symbols: $(\bullet)$ : $\mathrm{NH}_{4}-\mathrm{N}$ concentration, (口): phenol concentration and $(0)$ : Dissolved oxygen (DO) concentration.

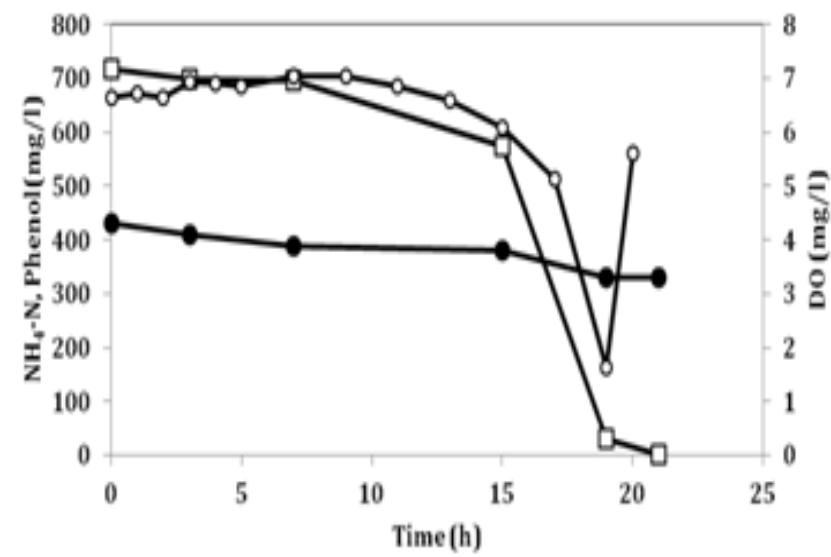

Figure 2 Removal of ammonium and phenol in synthetic medium, where phenol is a sole carbon source by No.4 when lactate and phenol were used as a carbon source in pre-culture.

Symbols: $(\bullet)$ : $\mathrm{NH}_{4}-\mathrm{N}$ concentration, (): phenol concentration and $(\mathrm{O})$ : Dissolved oxygen (DO) concentration. 


\section{Ammonium removal when lactate and phenol were mixed in synthetic medium}

The No.4 cells prepared in the pre-culture containing phenol were introduced into the synthetic medium containing lactate and phenol. The change in concentrations of ammonium, phenol and lactate is shown in Figure 3. The initial ammonium-nitrogen concentration, phenol concentration and lactate concentration were $733 \mathrm{mg} / 1,636 \mathrm{mg} / 1$ and $4.8 \mathrm{~g} / \mathrm{l}$, respectively. In this case, higher amount of ammonium was added to observe the clear change of phenol and lactate. At the exhaustion of lactate, approximately $500 \mathrm{mg} / 1$ of ammoniumnitrogen was utilized and after the decline in lactate concentration, phenol degradation started and $50 \mathrm{mg} / \mathrm{l}$ of ammonium-nitrogen was consumed. This shows that lactate consumption begins first and subsequently the consumption of phenol takes place. The initial cell number of No.4, $2 \times 10^{8} \mathrm{cells} / \mathrm{ml}$, increased to $8 \times 10^{9} \mathrm{cells} / \mathrm{ml}$.

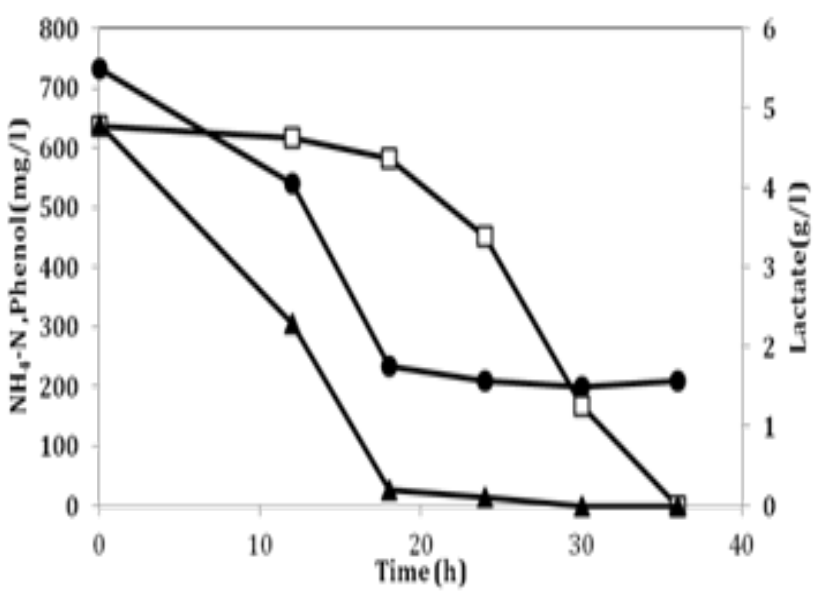

Figure 3 Removal of ammonium, phenol and lactate in the synthetic medium.

Symbols: $(\bullet): \mathrm{NH}_{4}-\mathrm{N}$ concentration, $(\square)$ : Phenol concentration and $(\boldsymbol{\Delta})$ : Lactate concentration.

\section{Coking wastewater treatment by No.4}

The No. 4 culture was directly mixed with crude coking wastewater with fortified lactate in a jar fermenter but removal rates of ammonium and lactate were significantly decreased. The ammonium removal rates and phenol consumption rates were $0.014 \mathrm{~kg}-\mathrm{N} / \mathrm{m}^{3} /$ day and $0.0035 \mathrm{~kg} / \mathrm{m}^{3} /$ day, respectively. Presumably, toxic substances in coking wastewater inhibited the activity of No.4. This finding indicates that carbons in the crude wastewater were not degradable by No.4 and addition of organic acids may be needed for efficient treatment of ammonium and phenol. When $\mathrm{CW}$ was diluted the normal growth of No.4 was observed at $50 \%$ dilution. Next, $50 \%$ of dilution CW wastewater was mixed with No.4 pre-culture and $4 \mathrm{~g} / 1$ of lactate. The result is shown in Figure 4. The initial ammonium-nitrogen concentration, phenol concentration and lactate concentration were $420 \mathrm{mg} / 1,380 \mathrm{mg} / 1$ and $4 \mathrm{~g} / 1$, respectively. The ammonium removal rate was $1.8 \mathrm{~kg}-\mathrm{N} / \mathrm{m}^{3} /$ day and phenol removal rate was $0.7 \mathrm{~kg} / \mathrm{m}^{3} /$ day. The ammonium removal rate was $50-60$ times higher than the previous results that treated phenol. ${ }^{4,5}$ Phenol removal rate $0.7 \mathrm{~kg} / \mathrm{m}^{3} /$ day was two times larger than that in the previous report. ${ }^{5}$

COD in the initial wastewater containing lactate was $12,000 \mathrm{mg} / 1$ and after the treatment this value decreased to $2,830 \mathrm{mg} / 1$. The COD of $50 \%$ diluted $\mathrm{CW}$ was $2,130 \mathrm{mg} / 1$. Thus, this ammonium treatment was primarily undertaken by No.4 by consumption of added lactate and indigenous phenol. These data indicate that addition of lactate stimulated the activity of No.4 and lactate, ammonium and phenol were removed simultaneously. When lactate concentration was significantly lower, the consumption of phenol was initiated. As coking wastewater contained some other carbon substances not available for No.4, further treatment may be needed for complete treatment of COD after this system. As we showed in previous papers, No.4 is useful for ammonium removal under high saline condition ${ }^{17,18}$ and the cells of No.4 have ability to suppress the plant pathogens ${ }^{21}$ and to reduce methane production from rumen. ${ }^{22}$ This suggests that the reutilization of the excess cells of No.4 after treatment is possible and this reduces the problem of handling of the excess sludge produced after wastewater treatment.

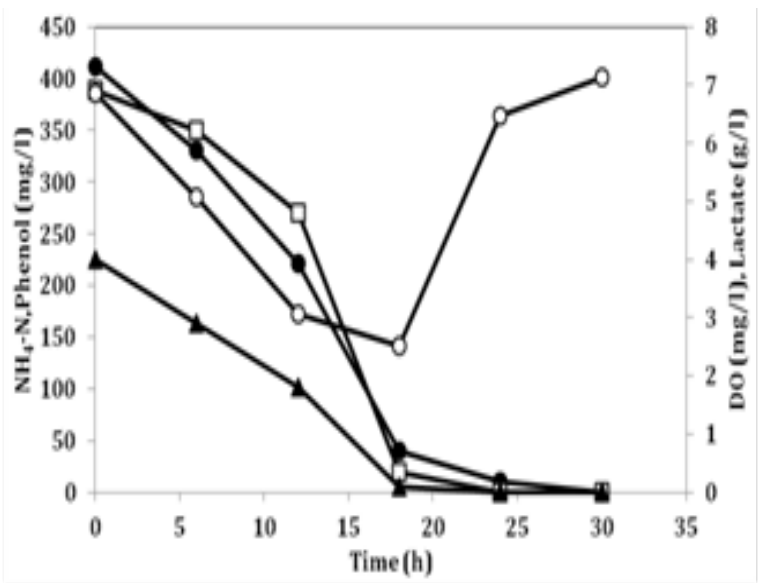

Figure 4 Removal of ammonium, phenol and lactate in coking wastewater.

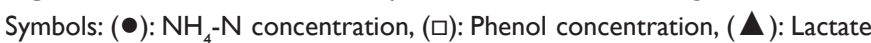
concentration and (O): Dissolved oxygen (DO) concentration.

\section{Conclusion}

Since A. faecalis No.4 exhibits phenol degradation activity the effects of its treatment on phenol-containing wastewater were determined under high-strength-ammonium condition. In pure culture, No.4 showed degradation ability for $700 \mathrm{mg} / 1$ phenol the concentration that was inhibitory to nitrifying bacteria. In the synthetic medium containing phenol, lactate and ammonium, all three components could be utilized when COD to nitrogen ratio is properly arranged. In diluted coking wastewater, $400 \mathrm{mg} / 1$ of ammoniumnitrogen and $380 \mathrm{mg} / \mathrm{l}$ of phenol were removed and the ammonium removal rate was 50 -fold larger than that reported in previous papers dealing with phenol treatment and 100-fold higher than that observed in the conventional ammonium treatment system.

\section{Acknowledgements}

None.

\section{Conflict of interest}

The author declares no conflict of interest.

\section{References}

1. Zhang M, Hwa Tay J, Qian Y, et al. Coke plant wastewater treatment by fixed biofilm system for $\mathrm{COD}$ and $\mathrm{NH}_{3}-\mathrm{N}$ removal. Water Research. 1998;32(2):519-527. 
2. Jianlonga W, Xiangchun Q, Libo W, et al. Bioaugmentation as a tool to enhance the removal, of refractory compound in coke plant wastewater. Process Biochemistry. 2002;38(5):777-781.

3. Haibo Li, Hongbin Cao, Yuping Li, et al. Innovative biological process for treatment of coking wastewater. Environmental Engineering Science. 2010;27(4):313-322

4. Lu J, Jin Q, He YL, et al. Simultaneous removal of phenol and ammonium using Serrati asp. LJ-1 capable of heterotrophic nitrification-aerobic denitrification. Water Air and Soil Pollution. 2014;225(9):1-10.

5. Qilong Ge, Xiuping Yue, Guoying Wang. Simultaneous heterotrophic nitrification and aerobic denitrification ay high initial phenol concentration by isolated bacterium Diaphorobacter sp. PD-7. Chinese Journal of Chemical Engineering. 2015;23(5):835-841.

6. Lei Y, Wang Y, Liu H, et al. A novel heterotrophic nitrifying and aerobic denitrifying bacterium, Zobellella taiwanensis DN-7, can remove high-strength ammonium. Applied Microbiology and Biotechnology. 2016;100(9):4219-4229.

7. Zhao B, He YL, Hughes J, et al. Heterotrophic nitrogen removal by a newly isolated Acinetobacter valcoaceticus HNR. Bioresource Technology. 2010;101(14):5194-5200.

8. Padhi, Tripathy SK, Sen S, et al. Characterisation of heterotrophic nitrifying and aerobic denitrifying Klebsiella pneumonia CF-S9 strain for bioremediation of wastewater. International biodeterioration \& biodegradation. 2013;78:67-73.

9. Yao S, Ni J, Ma T, et al. Heterotrophic nitrification and aerobic denitrification at low temperature by a newly isolated bacterium, Acinetobacter sp. HA2. Bioresource Technology. 2013;139:80-86.

10. Chen P, Li J, Li QX, et al. Simultaneous heterotrophic nitrification and aerobic denitrification by bacterium Rhodococus sp. CPZ24. Bioresour Technol. 2012;116:266-270.

11. Khardenavis AA, Kapley A, Purohit HJ. Simultaneous nitrification and denitrification by diverse Diaphorobacter sp. Applied Microbiology and Biotechnology. 2007;77(2):403-409.

12. Yang XP, Wang SM, Zhang DW, et al. Isolation and nitrogen removal characteristics of an aerobic heterotrophic nitrifying-denitrifying bacterium, Bacillus subtilis A1. Bioresource Technology. 2011;102(2):854-862.
13. Zhang QL, Liu Y, Ai GM, et al. The characteristics of a novel heterotrophic nitrification-aerobic denitrification bacterium, Bacillus methylotrophicus strain L7. Bioresource Technology. 2012;108:35-44.

14. Zhao B, An Q, He YL, et al. $\mathrm{N}_{2} \mathrm{O}$ and $\mathrm{N}_{2}$ production during heterotrophic nitrification by Alcaligenes faecalis strain NR. Bioresource Technology. 2012;116:379-385.

15. Joo HS, Hirai M, Shoda M. Nitrification and denitrification in highstrength ammonium by Alcaligenes faecalis. Biotechnology Letters. 2005;27(11):773-778.

16. Joo HS, Hirai M, Shoda M. Piggery wastewater treatment using $A l$ caligenes faecalis strain No.4 with heterotrophic nitrification and aerobic denitrification. Water Research. 2006;40(16):3029-3036.

17. Shoda M, Ishikawa Y. Heterotrophic nitrification and aerobic denitrification of high-strength ammonium in anaerobically digested sludge by Alcaligenes faecalis No.4. Journal of Bioscience and Bioengineering. 2014;117(6):737-741.

18. Shoda M, Ishikawa Y. Heterotrophic nitrification and aerobic denitrification of a wastewater from a chemical company by Alcaligenes faecalis No.4. International Journal of Water and Wastewater Treatment. 2015;1(2):1-5.

19. Kuai L, Verstraete W. Ammonium removal by the oxygen-limited autotrophic nitrification-denitrification system. Applied and Environmental Microbiology. 1998;64(11):4500-4506.

20. Rostron WM, Stuckey DC, Young AA. Nitrification of high-strength ammonia wastewater: comparative study of immobilized media. Water Research. 2001;35(5):1169-1178

21. Honda N, Hirai M, Ano T, et al. Control of tomato damping-off caused by Rhizoctonia solani by the heterotrophic nitrifier Alcaligenes faecalis and its product, hydroxylamine. Annals of the Phytopathological Society of Japan. 1999;65:153-162.

22. Obrien M, Shoda M, Nishida T, et al. Synergistic effect of Alcaligenes faecalis and nitrate to reduce in vitro rumen methanogenesis. Proceedings of the $5^{\text {th }}$ International Conference on Greenhouse Gases and Animal Agriculture; Dublin, Ireland; 2013. 